DR-28

\title{
SILICA GEL WITH COVALENTLY IMMOBILIZED IMIDAZOLIUM SALT AS A NEW STATIONARY PHASE FOR ION CHROMATOGRAPHY
}

\author{
D. A. Chuprynina, I. A. Lupanova, Dzh. N. Konshina, and V. V. Konshin ${ }^{a}$ \\ Department of Chemistry \& High Technology, Kuban State University, 149 Stavropolskaya St., \\ 350040 Krasnodar, Russian Federation \\ ${ }^{a}$ Corresponding author, E-mail: organotin@mail.ru
}

\begin{abstract}
The development of new anion-exchange stationary phases with improved selectivity and performance is one of topical problems in modern ion chromatography. Various classes of organic compounds are used as surface modifiers of the stationary phase matrix. In recent years, there is an increased interest in the use of ionic liquids allowing one to vary the nature of cation moiety in a wide range, which provides a way to control properties of materials on their basis. Earlier, our team has prepared and characterized silica gel with covalently immobilized imidazolium salt (with a particle size of 40-60 $\mu \mathrm{m}$ ) and studied its ion-exchange characteristics in the solid-phase extraction of $\mathrm{Pd}(\mathrm{II})$ in chloride media. It seemed interesting to obtain similar material with a particle size of 8-12 $\mu \mathrm{m}$ and to determine whether it can be used as a stationary phase in ionexchange chromatography.
\end{abstract}

The research object was a covalently modified silica gel:

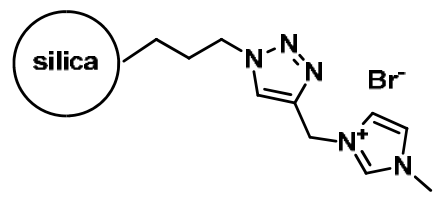

Chromatographic properties of the modified silica gel were studied using the single-column non-suppressed version of ion chromatography with conductometric detection, for which purpose a chromatographic column (stainless steel, $150 \times 2 \mathrm{~mm}$ ) was packed by the suspension technique under pressure and ultrasonic exposure. A mixture of $\mathrm{F}^{-}, \mathrm{CH}_{3} \mathrm{COO}^{-}, \mathrm{IO}_{3}^{-}, \mathrm{Cl}^{-}, \mathrm{NO}_{2}^{-}, \mathrm{Br}^{-}, \mathrm{NO}_{3}^{-}, \mathrm{SCN}^{-}$, and $\mathrm{SO}_{4}{ }^{2-}$ ions was used as a test model. The modified silica gel showed the highest performance as a stationary phase upon separation of $\mathrm{F}^{-}, \mathrm{CH}_{3} \mathrm{COO}^{-}, \mathrm{IO}_{3}^{-}, \mathrm{Cl}^{-}, \mathrm{NO}_{2}{ }^{-}, \mathrm{Br}^{-}, \mathrm{NO}_{3}^{-}$, and $\mathrm{SCN}^{-}$in the case when a $\mathrm{pH} 4$ hydrophthalate eluent was used $\left(17546 \mathrm{tp} / \mathrm{m}\right.$ with respect to $\mathrm{Br}^{-}$and $10000 \mathrm{tp} / \mathrm{m}$ with respect to $\left.\mathrm{NO}_{2}^{-}\right)$. In using a pH 5.5 eluent, it became possible to determine the strongly retained $\mathrm{SO}_{4}{ }^{2-}$ ion. Under selected conditions of analysis, the peak resolution of determined anions varied from 0.74 to 3.3. The LODs of $\mathrm{Cl}^{-}, \mathrm{Br}^{-}, \mathrm{NO}_{3}{ }^{-}$, and $\mathrm{NO}_{2}{ }^{-}$were from 1.6 to $3.8 \mathrm{mg} / \mathrm{L}$ and the $\mathrm{LOD}$ of $\mathrm{SO}_{4}{ }^{2-}$ was $12.3 \mathrm{mg} / \mathrm{L}$.

\section{References}

1. Konshina, D. N., Lupanova, I. A., Mazur, A. S., Konshin, V.V. Solvent Extraction and Ion Exchange. doi.org/10.1080/07366299.2019.1665242

This work was financially supported by the Ministry of Science and Higher Education of the Russian Federation (project no. 4.4892.2017). This work was accomplished with the use of scientific equipment of the Collective Employment Centre "Ecoanalytical Centre", Kuban State University. 